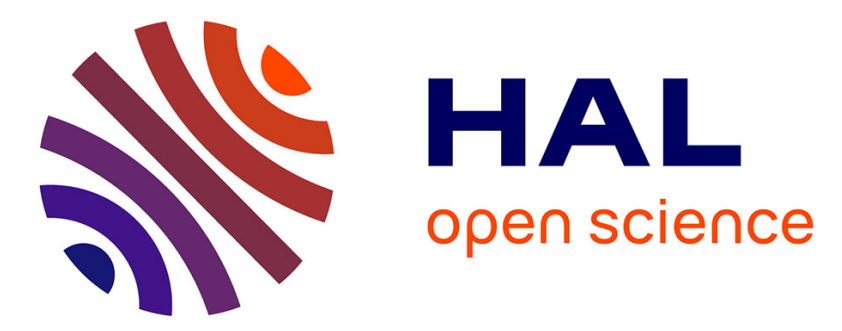

\title{
Accelerated ovulation by pelleted LHRH analogue treatment of spring-spawning rainbow trout (Salmo gairdneri) held at low temperature
} L.W. Crim, A.M. Sutterlin, D.M. Evans, Claudine Weil

\section{- To cite this version:}

L.W. Crim, A.M. Sutterlin, D.M. Evans, Claudine Weil. Accelerated ovulation by pelleted LHRH analogue treatment of spring-spawning rainbow trout (Salmo gairdneri) held at low temperature. Aquaculture, 1983, 35, pp.299-307. 10.1016/0044-8486(83)90102-3 . hal-01600565

\section{HAL Id: hal-01600565 https://hal.science/hal-01600565}

Submitted on 2 Jun 2020

HAL is a multi-disciplinary open access archive for the deposit and dissemination of scientific research documents, whether they are published or not. The documents may come from teaching and research institutions in France or abroad, or from public or private research centers.
L'archive ouverte pluridisciplinaire HAL, est destinée au dépôt et à la diffusion de documents scientifiques de niveau recherche, publiés ou non, émanant des établissements d'enseignement et de recherche français ou étrangers, des laboratoires publics ou privés.

\section{다(1)(2)}

Distributed under a Creative Commons Attribution - ShareAlikel 4.0 International 


\title{
ACCELERATED OVULATION BY PELLETED LHRH ANALOGUE TREATMENT OF SPRING-SPAWNING RAINBOW TROUT (SALMO GAIRDNERI) HELD AT LOW TEMPERATURE
}

\author{
L.W. CRIM, A.M. SUTTERLIN, D.M. EVANS and C. WEIL* \\ Marine Sciences Research Laboratory, Memorial University of Newfoundland, St. John's, \\ NFld. A1C 5S7 (Canada)
}

*Laboratoire de Physiologie des Poissons, I.N.R.A., 78350 Jouy-en-Josas (France)

(Accepted 2 February 1983)

\section{ABSTRACT}

Crim, L.W., Sutterlin, A.M., Evans, D.M. and Weil, C., 1983. Accelerated ovulation by pelleted LHRH analogue treatment of spring-spawning rainbow trout (Salmo gairdneri) held at low temperature. Aquaculture, 35: 299-307.

Pelleted LHRH analogue formulated for long term hormone delivery was administered by two routes to maturing, spring spawning, female rainbow trout in an attempt to accelerate spawning. At water temperatures ranging from $0.5-2.0^{\circ} \mathrm{C}$, spawning was advanced by approximately 27 days. Rapid increases in the level of plasma gonadotropic hormone at 2 weeks indicates that pituitary stimulation occurred well in advance of ovulation, despite low temperatures. Egg diameter and fertility were comparable in sham control and experimental fish. Heavy mortalities occurred in eggs taken from accelerated spawners, however, eggs from $35 \%$ of these females were still viable at the eyed stage. Although further studies directed at egg quality appear warranted, pelleted LHRH implants could prove useful in advancing spawning time in order to meet schedules of smolt production or assist in synchronizing the spawning time of salmonid brood stock reared or held in salt water.

\section{INTRODUCTION}

Cage culture in the sea of salmonid fishes is a currently popular method of aquatic farming under conditions designed to optimize growth in temperate climates. The restricted growing season places a special importance upon early spawning so that smolt size and salt water tolerance can be advanced as far as possible. In Newfoundland, spring spawning stocks of rainbow trout normally spawn in late April following ice-breakup; accelerated spawning could represent an opportunity to advance fry growth in anticipation of the summer growing period in brackish water ponds.

Several reports have now appeared in the literature suggesting that gonadotropin releasing hormone (LHRH) and/or some commercially available 
agonist analogues of LHRH (LHRH-A) can be used to advance the breeding period of Pacific and Atlantic salmon (review by Crim, 1983). The present experiment was designed to examine the possibility of utilizing a longacting formulation of LHRH analogue to accelerate spawning of rainbow trout held in fresh water at low temperatures ranging from $0-3^{\circ} \mathrm{C}$.

\section{MATERIALS AND METHODS}

\section{Experimental animals}

A spring-spawning stock of rainbow trout, average body weight $600 \mathrm{~g}$ $\pm 118 \mathrm{~g}$ (S.D.) were held in 4- $\mathrm{m}^{2}$ fiberglass tanks in ambient freshwater at the trout farm in Hopeall, Newfoundland. The fish were fed once a day to satiation on a homemade moist pellet.

On September 15 and November 2, 1981 and again on February 27, 1982 a group of female trout were killed to obtain information about the state of gonadal development (GSI) at various times prior to spawning. On March 4 (day 1), approximately 2 months before the anticipated spawning time and the day the experiment was initiated, another group of females and males were bled to provide baseline data for plasma gonadotropic hormone levels. Six experimental groups, each consisting of seven female trout, were treated as follows: (1) surgical sham control; (2) low dose LHRH-A surgical implant; (3) high dose LHRH-A surgical implant; (4) egg pore sham control; (5) low dose LHRH-A via egg pore; (6) high dose LHRH-A via egg pore. A 3-mm diameter pellet containing LHRH analogue (D-Trp ${ }^{6}$-desGly ${ }^{10}$-ethylamide) LHRH, approximately 100X more active than LHRH in mammals (Nestor Jr. et al., 1982), was inserted through a straw into the perivisceral cavity either directly via the egg pore or surgically by means of a small $(0.5-\mathrm{cm})$ incision in the ventral body wall which did not require sutures. The compacted cholesterol pellets containing either low dose $(0.1 \%=25 \mu \mathrm{g}$ total $)$ or high dose $(0.5 \%=125 \mu \mathrm{g}$ total $)$ of LHRH analogue were tested.

\section{Blood sampling and checking for maturity}

Heparinized syringes were used to collect blood samples at various times after administration of the releasing hormone pellet. On a weekly basis the state of maturity was determined following brief anesthesia by ovary palpation and examination of egg pore swelling. When females were soft enough for stripping, the eggs were hand stripped and fertilized with the pooled milt collected from two males. The eggs from trout of different experimental groups were fertilized at ambient water temperatures which varied from $1-10^{\circ} \mathrm{C}$ depending on the time of ovulation.

\section{Plasma gonadotropic hormone (GtH) analysis}

GtH was determined by radioimmunoassay method previously described (Crim et al., 1975). 


\section{Statistical analysis}

The $\log _{10}$ GtH values (Table II) were compared using one-way ANOVA and Duncans Multiple Range Test $(P \leqslant 0.05)$.

\section{Egg quality}

Approximately 300 eggs from each female were water hardened and set down in petri dishes in a trough of running water at ambient temperature. Dead eggs were recorded and removed daily. One week after fertilization, approximately 50 eggs were removed from each dish and mean egg diameter was determined by aligning the eggs in a v-shaped trough. The eggs were then placed in $3 \%$ acetic acid and the fertility (presence or absence of blastodisc) was determined microscopically.

\section{RESULTS}

Seasonal gonadal development in the Hopeall spring-spawning stock of rainbow trout begins in the fall in advance of the very low, near freezing winter water temperatures. In September and November the mean gonadosomatic index (GSI) of the Hopeall female rainbow trout was $2.20 \pm 0.42$ and $6.64 \pm 1.32$, respectively. Continued ovary growth is evident by February when GSI reaches $12.1 \pm 1.0$ and egg diameter averages $4.2 \mathrm{~mm}$. According to hatchery records this stock of rainbow trout has spawned consistently during the last week in April (GSI $=16.2 \pm 3.7$ ) for the past 3 years.

The ovulatory responses of females receiving the LHRH analogue treatment compared with the sham control fish are recorded in Fig. 1. The first ovulated eggs were collected from a hormone treated female on Day 14 (March 17). At 2 weeks following insertion of the LHRH-A pellet, a palpable softening of the ovarian mass and increased plasma GtH levels (Table II) suggested that a number of the hormone treated females were nearing ovulation. The majority of LHRH-A treated females had been spawned by Day 28 (March 31); during the interim, water temperatures remained below $2^{\circ} \mathrm{C}$ (Fig. 1). By Day 34 none of the 14 sham control fish ovulated. In contrast, 11 of 14 and 12 of 13 females receiving low and high hormone dose pellets, respectively, were in ovulated condition and ready for spawning. The fish were checked again and blood samples were obtained at the end of April (Day 58). This was the day chosen for spawning the bulk of the population of Hopeall brood stock based upon the high proportion of females discovered to be ready for stripping. By noting the difference in days required to achieve an ovulation rate $\geqslant 70 \%$ in hormone treated females (D-28) compared with sham control fish (D-55), ovulation was advanced 3-4 weeks by LHRH-A administration.

Blood samples were collected from a few undisturbed male and female trout brood stock to determine the plasma GtH value at the beginning of the experimental period (March 4) and also on the day of peak spawning (April 30 ) of Hopeall brood stock (310 (85\%) fish spawned on April 30, 1982). 


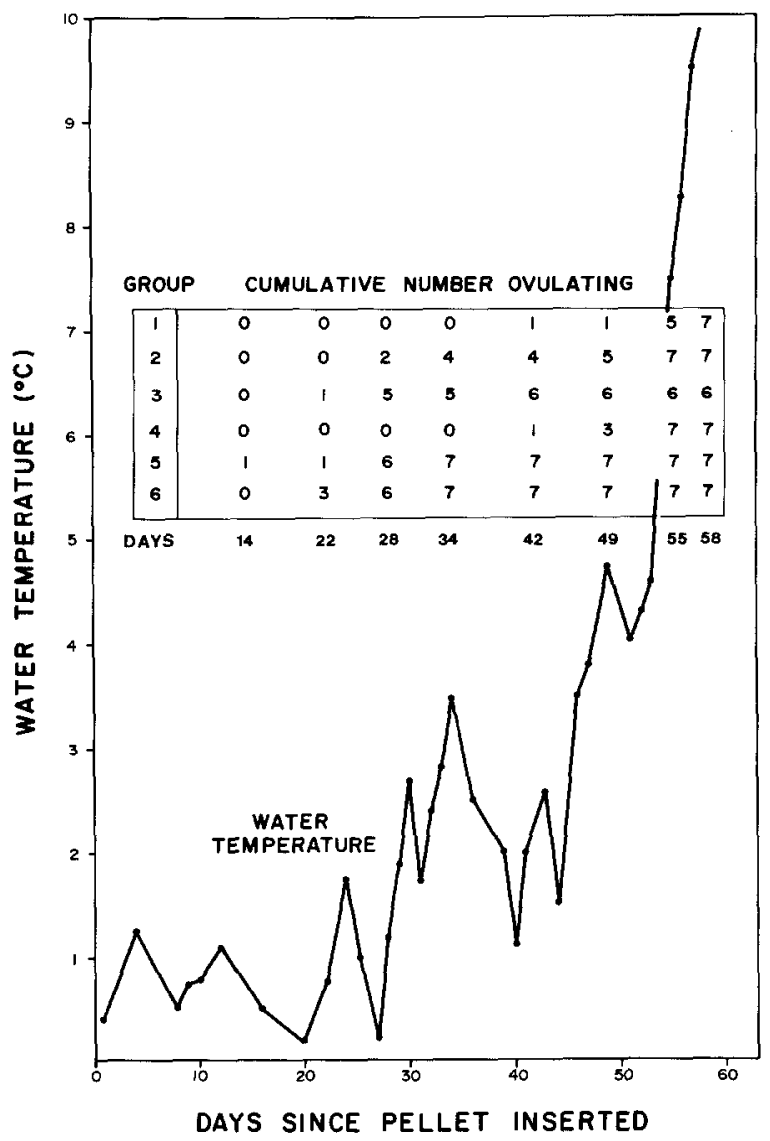

Fig. 1. Water temperature and post treatment ovulation time. The time of ovulation shown in the tabular insert is positioned to correspond with the time scale at the bottom of the graph. The treatments were initiated on March 4 (day 1). It should be noted that one fish in group 3 was found to be immature.

\section{TABLE I}

Plasma GtH ( $\mathrm{ng} / \mathrm{ml})$ values for randomly selected male and female Hopeall brood stock rainbow trout sampled at the beginning of the experiment in March and at the end of April on the day of spawning

\begin{tabular}{llll} 
& March 4 & April 30 & Significance $^{\mathrm{b}}$ \\
\hline Male & $3.48 \pm 0.54(5)^{\mathrm{a}}$ & $6.86 \pm 0.65(10)$ & $P<0.005$ \\
Female & $8.64 \pm 4.40(5)$ & $55.4 \pm 13.3(10)$ & $P<0.05$ \\
\hline
\end{tabular}

Values are mean \pm SEM.

${ }^{a}$ On March 4, four of five males spermiating.

${ }^{b}$ Significance comparing March and April means by Students $t$-test. 
Basal GtH levels were relatively low in early March (Table I); in spawning male and female trout circulating GtH was significantly elevated (end of April).

Plasma GtH values for the period March 17-May 28 are recorded in Table II for sham control fish and the females treated with either low or high dose LHRH-A pellets. Blood samples were collected at 2, 4 and approximately 8 and 12 weeks after LHRH-A administration. Circulating GtH was significantly elevated for a period of 8 weeks in pellet treated females compared to GtH levels in control fish; however, GtH had declined by May 28 in post-spawned fish that had earlier received LHRH-A pellets (groups 2, 5 and 6). For the sham control fish, which were undergoing natural, unaccelerated spawning, the highest GtH levels were observed on the day of egg collection (April 30 ) compared with pre- and post-spawning GtH values.

The egg diameter of accelerated, high and low dose LHRH-A treated fish did not differ significantly from the control fish that spawned later $(4.85 \pm$ $0.53 \mathrm{~mm}$ vs $4.68 \pm 0.67 \mathrm{~mm}$, respectively). Approximately $2 \%$ of the eggs from all groups turned white after water hardening, and an additional 5\% were removed during the first week of incubation. Examination of samples of the remaining eggs after $6-8$ days of incubation revealed $100 \%$ fertility in all six groups. Eggs taken from both groups of high dose females exhibited high rates of mortality $(50-70 \%)$ at $15-21$ days after fertilization at which time they were still in the pre-eyed stage. High temperatures, silt and fungus problems resulted in the loss of many control and experimental groups of eggs in early May and the incubation trials were terminated on May 10. At that time, five of 13 batches of eggs from high dose females contained eggs with eyed embryos. However, survival to the eyed-stage was low, ranging from 4-30\%. Survival of eggs from low dose females was similar, and considerably below the $70-80 \%$ obtained by hatchery personnel using the same brood stock that year.

\section{DISCUSSION AND CONCLUSIONS}

The results of the present study clearly indicate that pelleted LHRH-A is effective in the rainbow trout for advancing the spawning period and allowing the collection of eggs at an earlier date. The LHRH-A pellets were surgically implanted into the body cavity or hormone pellets were conveniently inserted in anaesthetized fish directly into the body cavity via the egg pore. In both cases the acceleration of spawning was very similar. The interest in LHRH-A is increasing as it becomes evident from several recent studies that this commercially available hormone can be used successfully to manipulate the teleost reproductive cycle. To date, LHRH-A has proven to be effective in the female coho salmon (Donaldson et al., 1981; Sower et al., 1982) where prespawning mortalities were significantly reduced by accelerating spawning of fish returning from the sea. In another fall spawner, the 


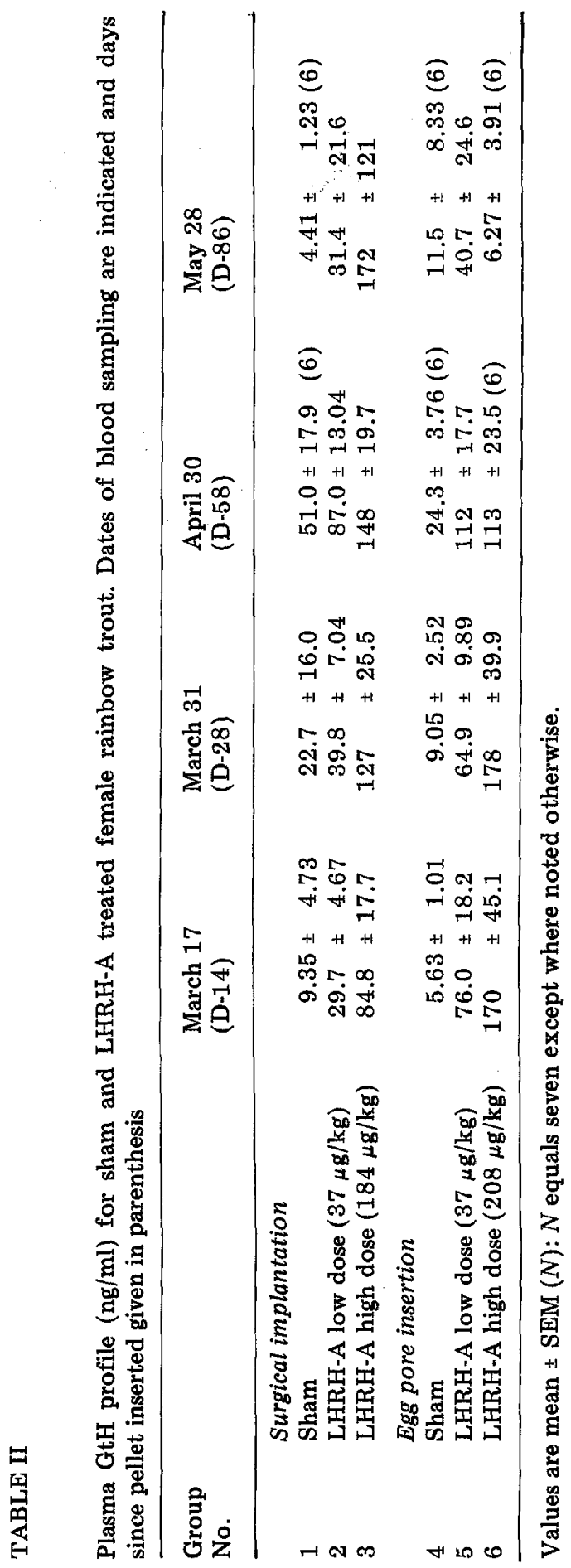


landlocked Atlantic salmon, LHRH-A also advances the spawning period in females and males (Crim et al., 1983; Weil and Crim, 1983).

In Newfoundland, fall spawning stocks of salmon and trout undergo the final stages of oocyte development at temperatures considerably higher than the rainbow trout which spawns in the spring soon after ice break-up. Development of the rainbow trout gonads appears to occur throughout the winter. Females normally ripen and become ready for stripping late in April; the males mature and are usually in spermiating condition earlier in March.

A question of particular interest in this study was the determination of whether or not trout were responsive to LHRH-A at such low environmental temperatures. Previous investigators had already examined trout (fall spawning) pituitary sensitivity to LHRH on a seasonal basis (Crim and Cluett, 1974; Weil et al., 1978) but no effort was made to analyze the results with respect to the influence of temperature. In March, with water temperatures ranging between $0-2^{\circ} \mathrm{C}$, plasma gonadotropin levels in the rainbow trout were elevated within 2 weeks following administration of the pelleted LHRH-A. Within 4 weeks ovulation was clearly underway in many females of the LHRH-A treated groups, approximately 27 days in advance of the expected spawning time for this rainbow trout population. Induction of spawning by LHRH-A produced a plasma GtH profile similar to previous reports of the hormone changes in spawning salmonids. The plasma GtH level is augmented in ovulating trout and salmon (Crim et al., 1975; Billard et al., 1978) and following ovulation plasma GtH remains elevated for an extended period especially in females retaining ovulated eggs (Jalabert and Breton, 1980). The ovulatory process in the present study appeared to be abnormally prolonged, since some eggs (not all) could be stripped from many fish beginning at 3 weeks and again at 4 weeks. Very likely this was due to some females being in partially ovulated condition; however, egg quality did not seem to vary greatly between females stripped all at once or those with eggs harvested on repeated occasions. Retained ovulated eggs in the rainbow trout may remain fertile for 30 days (Escaffre et al., 1977) although overripening of eggs has been noted after 10 days by Nomura et al. (1974) and Sakai et al. (1975). At these low temperatures eggs have an unknown period of fertilizability while remaining in the body cavity.

LHRH and LHRH agonists are highly water soluble agents. Kent et al. (1980) devised a cholesterol matrix system to extend the biologically effective period for applications of small amounts of these peptide hormones over many days. Administration of LHRH-A in saline was not included as part of this study since it was 2 months before the time of expected spawning and we felt it was advantageous to be able to administer LHRH-A once with long lasting effects. This seemed to be the case since plasma GtH was elevated for at least 8 weeks following LHRH-A implantation. A single implantation of fish with releasing hormone could reduce the quantity of hormone required, minimize the stress often accompanying protocols requiring multiple hormone injections and also reduce labour costs. The minimum dose of LHRH- 
A required was not determined in this study because both $25 \mu \mathrm{g}$ and $125 \mu \mathrm{g}$ LHRH-A pellets were effective. The high dose LHRH-A pellet contains sufficient peptide hormone to also advance ovulation in sea cage-reared Atlantic salmon weighing as much as $5.8 \mathrm{~kg}$ (L.W. Crim and B.D. Glebe, unpublished results).

Although the incubation trials indicate that acceptable egg size and levels of fertility were obtained in eggs taken from LHRH-A accelerated females, and that some eggs were capable of developing to eyed stage, the results of the experiments were complicated by abnormally low incubation temperatures and unknown losses attributed to silt and fungus. Eggs taken from LHRH-A treated females were incubated at unusually low temperatures ranging from 1 to $6^{\circ} \mathrm{C}$. The more normal situation for this stock of trout entails spawning at $6-7^{\circ} \mathrm{C}$ with subsequent incubation temperature ranging from 7 to $12^{\circ} \mathrm{C}$. To accurately assess egg quality, the holding temperature of treated, prespawning females, the temperature at fertilization, and the temperature at which the eggs are incubated, should be maintained constant, preferably between 6 and $8^{\circ} \mathrm{C}$.

\section{ACKNOWLEDGEMENTS}

The authors wish to thank Messrs. Bub Woodman and Lew Higdon of the Upper Trinity Regional Development Association for their diligent assistance with care of experimental fish and eggs after spawning. Pelleted LHRH-A was kindly supplied by Dr. B.H. Vickery of Syntex Research, Palo Alto, California.

The project was supported by NSERC Grant No. A9729 to L.W.C. and a grant from the Department of Fisheries of Newfoundland and Labrador to A.M.S. M.S.R.L. Contribution Number 504.

\section{REFERENCES}

Billard, R., Breton, B., Fostier, A., Jalabert, B. and Weil, C., 1978. Endocrine control of the teleost reproductive cycle and its relation to external factors: salmonid and cyprinid models. In: P.J. Gaillard and H.H. Boer (Editors), Comparative Endocrinology. Elsevier/North-Holland/Biomedical Press, Amsterdam, pp. 37-48.

Crim, L.W., 1983. Actions of LHRH and its analogs in lower vertebrates. In: B.H.Vickery, J.J. Nestor Jr. and E.S.E. Hafez (Editors), LHRH and Its Analogs - A New Class of Contraceptive and Therapeutic Agents. MTP Press, Lancaster - Boston - The Hague, in press.

Crim, L.W. and Cluett, D.M., 1974. Elevation of plasma gonadotropin concentration in response to mammalian gonadotropin releasing hormone (GRH) treatment of the male brown trout as determined by radioimmunoassay. Endocr. Res. Commun., 1: 101110.

Crim, L.W., Watts, E.G. and Evans, D.M., 1975. The plasma gonadotropin profile during sexual maturation in a variety of salmonid fishes. Gen. Comp. Endocrinol., 27: 62-70. 
Crim, L.W., Evans, D.M. and Vickery, B.H., 1983. Manipulation of the seasonal reproductive cycle of the landlocked Atlantic salmon (Salmo salar) by LHRH analogues administered at various stages of gonadal development. Can. J. Fish. Aquat. Sci., 40: $61-67$.

Donaldson, E.M., Hunter, G.A. and Dye, H.M., 1981. Induced ovulation in coho salmon (Oncorhynchus kisutch). II. Preliminary study of the use of LH-RH and two high potency LH-RH analogues. Aquaculture, 26: 129-141.

Escaffre, A., Petit, J. and Billard, R., 1977. Evolution de la quantité d'ovules récoltes et conservation de leur aptitude a être fécondés au cours de la période post ovulatoire chez la truite arc-en-ciel. Bull. Fr. Piscic., 265: 134-142.

Jalabert, B. and Breton, B., 1980. Evolution de la gonadotropine plasmatique t-GtH après l'ovulation chez la truite arc-en-ciel (Salmo gairdneri R.) et influence de la rêtention des ovules. C.R. Acad. Sci. Paris, 290: 799-801.

Kent, J.S., Vickery, B.H. and McRae, G.I., 1980. The use of a cholesterol matrix pellet implant for early studies on the prolonged release in animals of agonist analogues of luteinizing hormone releasing hormone. Paper presented at the $7 \mathrm{th}$ Int. Symp. Controlled Release of Bioactive Materials, Fort Lauderdale, FL.

Nestor, Jr. J.J., Ho, T.L., Simpson, R.A., Horner, B.L., Jones, G.H., McRae, G.I. and Vickery, B.H., 1982. Synthesis and biological activity of some very hydrophobic superagonist analogues of luteinizing hormone releasing hormone. J. Med. Chem., 25 : $795-801$.

Nomura, M., Sakai, K. and Takashima, F., 1974. The over-ripening phenomenon of rainbow trout. I - Temporal morphological changes of eggs retained in the body cavity after ovulation. Bull. Jpn. Soc. Sci. Fish., 40: 977-984.

Sakai, K., Nomura, M., Takashima, F., Oto, H., 1975. The over-ripening phenomenon of rainbow trout. II - Changes in the percentage of eyed eggs, hatching rate, and incidence of abnormal alevins during the process of over-ripening. Bull. Jpn. Soc. Sci. Fish., $41: 855-860$.

Sower, S.A., Schreck, C.B. and Donaldson, E.M., 1982. Hormone-induced ovulation of coho salmon (Oncorhynchus kisutch) held in seawater and fresh water. Can. J. Fish. Aquat. Sci., 39:627-632.

Weil, C. and Crim, L.W., 1983. Administration of LHRH analogues in various ways: effect on the advancement of spermiation in prespawning landlocked salmon, Salmo salar. Aquaculture, 35: 103-115.

Weil, C., Billard, R., Breton, B. and Jalahert, B., 1978. Pituitary response to LH-RH at different stages of gametogenesis in the rainbow trout (Salmo gairdneri). Annal. Biol. Anim. Biochim. Biophys., 18: 863-869. 